\title{
EU-TURKEY RELATIONS IN THE RADICAL NATIONALIST DISCOURSE: THE NATIONALIST ACTION PARTY (MHP)
}

\author{
ŞERMIN KORKUSUZ*
}

Ankara University

\begin{abstract}
The objective of this study is to analyze the discourse of the radical nationalist perspective about Turkey-EU relations from the 1990s to 2008. The EU is discussed as an actor within the globalization process. Therefore, in a broader context, the study will present the situation of the radical nationalist perspective in Turkey within the globalization process. In the study, the Milliyetçi Hareket Partisi (Nationalist Action Party, MHP) has been selected as the political representative of radical nationalism in Turkey. The party's official discourse is focused on the relations with the EU. In this framework, the party's perception of the EU, of Turkey-EU relations and of Turkey's position in these relations will be analyzed concerning the themes prominent in its discourse. While doing this, we will also try to reveal contradictions, uncertainties and ambivalences.
\end{abstract}

Keywords: Nationalism, Turkish nationalism, Nationalist Action Party (MHP), globalization, European Union $(\boldsymbol{E U})$.

\section{RADİKAL MİLLIYYETÇI SÖYLEMDE AB-TÜRKIYYE İLIŞKİLERİ: MILLIYETÇİ HAREKET PARTISİ (MHP)}

\section{ÖZET}

Bu çalışmanın amacı radikal milliyetçi perspektifin, Türkiye-AB ilişkileri konusunda 1990’lardan 2008'e kadar uzanan dönemdeki söylemini çözümlemektir. AB, küreselleşme sürecinin bir aktörü olarak ele alınmıştır. Dolayısıyla çalışma daha geniş çerçevede Türkiye'deki radikal milliyetçi perspektifin küreselleşme sürecindeki durumunu ortaya koyacaktır. Çalışmada radikal milliyetçiliğ̈in siyasi temsilcisi olarak Milliyetçi Hareket Partisi (MHP) seçilmiştir. Partinin AB ile ilişskilere yönelik resmi söylemine odaklanılmıştır. Bu çerçevede, Parti'nin AB'yi, Türkiye-AB ilişkilerini, bu ilişkilerde Türkiye’nin konumunu, kendini ve diğer aktörleri nasıl algıladı̆̆ ç̧özümlenmiştir. Söyleminde hangi temaların ön plana çıktı̆̆g analiz edilmiştir. Bu yapılırken de söylemdeki çelişkiler, kararsızlıklar ve ikilemler ortaya konmaya çalışılmıştır.

Anahtar kelimeler: Milliyetçilik, Türk milliyetçiliği, Milliyetçi Hareket Partisi (MHP), küreselleşme, Avrupa Birliği $(A B)$.

* Şermin Korkusuz is a Ph.D. candidate in the Department of Political Science and Public Administration at Ankara University, 06590, Cebeci, Ankara, Turkey. E-mail: serminus@gmail.com 
The transnational/supranational nature of globalization gave rise to various debates on the future of nations. Some thinkers claim that nation-states will be eliminated; some claim that they will get even stronger; and some claim that they will be transformed and acquire new characteristics. In addition, there are some views suggesting that the process will activate nationalist movements. Regardless of their predictions about the position of nationalism within the globalization process, all these views suppose that there is a tension between nationalist movements and globalization. The influence of globalization is studied especially in the radical right/nationalist movements arising in Europe since the 1990s.

Transnational organizations are among the most important actors in the globalization process. The EU is among the most significant of these institutions. The member countries face at a concrete level the changes proposed by the globalization process through membership in the EU. Therefore, looking into the debates on the EU will also provide us with information about the positions concerning globalization.

In Turkey, the views of radical nationalists loom large in the debates over the EU. In the political life of Turkey, the MHP drew attention with its Turkist ideas, and sometimes obviously brought the anti-Westernist discourse to the forefront. It leaned toward the alliances that would be established with Turkic peoples rather than with Western states. In this respect, the EU has put pressure on the fundamental characteristics of the MHP. Therefore, it is considered that the debates over the EU would appear in a crystallized form in the MHP's discourse. In this line, this study analyses the discourse which the MHP has adopted on the course of EU-Turkey relations from the 1990s to 2008.

There are a couple of reasons as to why this study focuses more on the period in the 1990s. First, the collapse of the Soviets and the gains of independence of Turkic Republics influenced the MHP. Second, with the Customs Union Treaty (1996), an active period began in terms of the relations with the EU. Third, in the period after the 1990s, the MHP was first a coalition partner in the government (1999-2002), then extra-parliamentary (2002-2007), and finally a parliamentary opposition party (2007 to the present). Therefore, it is suitable to focus on this period for comparing the MHP's discourse in different political positions. Fourth, there are views suggesting that the MHP has been changed since the end of the 1980s; it has become more moderate and conciliatory down playing the Turkist and panTurkist elements. In this study, I will look into how the asserted change was reflected in the party's discourse on the EU.

In the study, the search is on how the MHP perceives the EU, Turkey, EU-Turkey relations, itself and the other actors in this period. In terms of methodology, this study relies mainly on analysis of the primary sources published by the MHP head office such as reports, tractates, booklets and statutes of the Party, the Party lines and speeches of Devlet Bahçeli in Parliament or in press statements.

While analyzing how the nationalist discourse in Turkey perceived the EU in particular and globalization in general, it becomes apparent that the MHP's perception evidences both changes and contradictions in the same time period.

\section{NATIONALISM IN THE GLOBALIZATION PROCESS}

One of the most important issues in the political aspect of the globalization debates is the transference of sovereignty to supra-national institutions. This brings along debates related to the future of 
nation-states in the globalization process. McGrew (2000: 140-142) states that the political aspect of globalization involves the following points: Political interactions have become supra-national, and as can be seen in the UN example, they are now institutionalized in an international manner. Connected to this, some thinkers assert that the nation-states will vanish (hyperglobalists); some assert that they will get even more important (skeptics), and some assert that they will be transformed (transformationists).

According to hyperglobalists, local and national differences, autonomy and sovereignty have been diminished, and a more homogenous global culture and economy have come into existence (Mackay, 2000: 46-55). In the near future, regional administrations and global institutions will become more powerful than the state's autonomy and sovereignty. Nation-states are being eroded from the bottom by a superstructure which leads to political, economic and cultural integration on the global level on the one hand and through disintegration and decomposition in the context of micro-nationalisms on the other hand (Gelekçi, 2003: 193).

According to skeptics, globalization has not brought about changes that are as big as claimed. The exchange of goods and cultures and the liberal economic relations have continued from the nineteenth century. Nation-states hold their powerful position. The international system is still organized on the nation-state basis. Members of the international organizations, such as NATO and UN, are again nation-states. Nation-states are the ones having their militaries and holding the use of legitimate power on the territory under their sovereignty (Gelekçi, 2003: 88; Özkırımlı, 2008: 105).

According to those who approach globalization as a transformational process, nation-states are still powerful in economic, military and political terms. However, the process of globalization may have very complicated and unexpected consequences. Talking about full independence is impossible in the present day world. While handing part of their sovereignty over supra-national structures, nationstates continue to hold and even enhance their sovereignty in other fields (Özkırımlı, 2008: 105).

One of the most important points in nationalism debates on the socio-cultural aspect of the globalization process is the matter of uniformization and domination of a single global culture. Globalization means the process of leveling of the world's societies and the emergence of a single global culture (Keyman and Sarıbay, 1998: 9). Intense mutual interaction, as the fundamental characteristic of the process, gives rise to debates on culture.

On the other hand, not only homogenizing but also diversifying dimensions of globalization are talked about. Saribay (2002) says that globalization involves both repudiation and adoption. Adoption means the consumption of the cultural codes of Western societies by non-Western societies. As for repudiation, it takes place in two forms: Firstly, in the form of purification from the advanced societies' cultural codes or prevention of their intervention in local cultural codes. Secondly, in the form of dissemination of the belief that the West's cultural codes actually correspond to codes which exist in the local culture. Some views suggest that in this regard the process of globalization goes hand in hand with "localization."

According to some points of view, the globalization process is influential not only in the spread of nationalist movements but also in their form/degree. According to Hall, the erosion of nation-states, national economies and national identities are very dangerous. As the nation-state era is declining in the globalization process, national identity is being molded into an "over defensive" and "very 
dangerous" form by an aggressive racism. A return to the local identity arises generally as a reaction to globalization (Hall, 1998: 46-47, 54-57).

The globalization process can be said to affect nationalist movements in another respect too. The process causes inequalities in terms of information, ownership of the means of communication, and information flows (Mackay, 2000: 46-5). These inequalities, which also create economic gaps, become gradually deeper both in national and international terms. The excessive imbalance due to globalization paves the way for the rise of radical movements. Likewise, the globalization process renders human relations more dependent upon the market relationships. Therefore it dissociates and atomizes individuals and communities. Thus it increases the existential anxiety of individuals, and so their nervousness against others increases as well (Beck, 1999).

There are also various views about the rise and position of nationalist movements in the process of globalization. According to some views, rising nationalist movements are the remnants of previous nationalisms, and they will be wiped out in a short while. For another view, nationalism is the product and the producer of modernity. Global modernization had transformed our life styles largely and it brought about disintegration. In this disintegrating and alienating world, "nationalism is the means of controlling destructive effects of the mass social change." It is the popular force that legitimizes and gives meaning to the state's activity. Just like nations, nationalisms are also perpetual (Smith, 2002: xi-xxi).

These elements --sovereignty, common culture, territorial integrity-- are the basis of the modern state and the components of the nation. Therefore, they are the immediate concerns of nationalism. In this regard, nationalist reactions directed to globalization can be expected to concentrate on these points. Thus in this study these points formed the thematic framework which was used to discuss the MHP's approach to the EU.

When the above mentioned points are considered, nationalist movements can be thought to adopt a discourse that is directly against globalization. However, as stated by Erbaş (2000: 214) as well, the rapid and effective implementation of globalization is presented as "contemporaneity." Not to be involved in the process of globalization is seen as "backwardness" or "undevelopedness." If Turkey's objective of modernization is considered, the difficulty of being anti-globalization can be understood. Under these conditions, nationalist movements can be expected to remain in between two alternatives, namely, being anti-globalization (by adopting the elements that are claimed to vanish with globalization, and regenerating nationalism from this) and not seeming to be backward. This can render the globalization discourses of nationalist movements stuck/indecisive.

\section{NATIONALISM IN TURKEY AND MHP}

It will be helpful to glance over the history of the MHP and the sources that formed its institutional mentality in order to comprehend the origins of its views about the EU.

In the dissolution era of the Ottoman Empire, the notion of Turkism that spread among the intellectuals harbored two principal points: an establishment of a state which was based upon the sovereignty of the Turkish element in the Empire and a probable union with the Turks outside the Empire (Uzun, 2005: 97). However, there was not a national consciousness till the late period of the Empire. With the 
rise of nationalism, Ottoman intellectuals had become aware of linguistic, cultural and racial (ethnic) nationalism in the West. However; after all, they had not supported a nationalism that was based upon racial unity for a long time (Bayraktutan, 1996: 54).

Among the most important actors in the development of the conception of Turkism were the Turkist intellectuals who emigrated from Russia to the Ottoman Empire. Owing to them, Turkism became a political ideology in the $20^{\text {th }}$ century following its historical, philological and literary accumulation (Çalık, 1995: 96). These intellectuals studied the language, culture, economic development and history of the Turks.

The Constitutional Era had presented a favorable ground for the development of Turkism. The atmosphere was open to arguments of Turkism and the government of the Committee of Union and Progress was influential in propagating it. Turkism had started to have more radical characteristics from that period on. The principal target had turned out to be "to achieve the unity of a race." Thus, the aim of Turkists had been directed at a vast geography, and evolved into a utopia (Öğün, 1992: 19). Turanism/Pan-turkism had appeared as the ideal of gathering all Turks under the same flag.

Following World War I, the culturally based design of Turkism has been carried to a political ground. Its irredentist aspect had come into prominence during the War. Most of the Ottoman territory was carved up by the European states following the War. For this reason, Turkish nationalism gained a Turanist characteristic which was reactive and disposed to imperialism (Arslan, 2002: 302). If the whole process is considered, according to Taner Akçam, Turkish national identity was belated. It had the aim of catching up with other countries. This caused it to be aggressive (1995: 39).

A Turkist legacy coming from the Ottoman Empire formed a basis for the nationalism of the Republican period. However, the founding cadre of the Turkish Republic redefined nationalism during the establishment period of the Republic. In this way, Turkist-Turanist nationalism became differentiated from Atatürk nationalism/Kemalist nationalism. However, the Turkist-Turanist movement remained passive for a while (between the years 1923-1939) in the period following the establishment of the Republic. The nationalist movement limited itself to helping Turks who emigrated from various countries to Turkey, and to activities in the fields of literature and language. It avoided presenting a political agenda.

\section{Turkism During and Following World War II}

There is a common view that during World War II, the Turkist movement was used as a diplomatic means of maneuver by the state in order to prevent Turkey's participation in the war. The TurkistTuranist movement, which involved German propaganda, was supported by the government against the pressure from Germany. However, it was sometimes repressed in order to balancing the relationships with the Soviets.

Especially in 1941, when the Nazis attacked the Soviets, Turkist publications increased in number and they became more aggressive as well. Turkists expected Turkey to participate in the war on the side of Germany and to establish a Turan state which would also cover Turks living in the Soviet Union (Uzun, 2005: 251). 
During the war, Turkist ideology got into a process of organization and structuring. A large number of Turkist journals and newspapers began to be published. Actually, the Turkist movement that was becoming widespread in this period revealed a multipartite structure within itself with several opinions that differed only very slightly from each other. At this point, two names can be mentioned who had their influence on Turkist-Turanist thought as well as on the MHP later on. One of these names is Nihal Atsiz who was also influential in the 1930s. According to him, innate inequalities among human beings also exist among peoples/races. The Turkish race is superior. The Turk's original duty is the Turkification of the world. He considered ethnic groups that are not Turkish to be foreigners even if they spoke Turkish. Another influential name who had given shape to the Turkist-Turanist perspective is Reha Oğuz Türkkan. According to Türkkan, being governed by "foreign blood" and the racial intermingling lead to the erosion of nations. Also for Türkkan, the Turkish race is superior to all the other races. Turkism means the Turkification of Turkey. One should continually proceed to reach the Great Turkish Union (Özdoğan, 2002: 213).

An important characteristic of the Turkist-Turanist movement of the 1930s and especially the 1940s was its opposition to the policies of the Cumhuriyet Halk Partisi (Republican People's Party, CHP) especially in the fields of culture and education. In this regard, the Turkist-Turanist movement developed a reaction to the Westernization policy. It was functioning as an anti-modernization platform. The CHP and the elitist rulers were blamed for imitating the West without comprehending the real foundations of civilization and also for becoming degenerate (Özdoğan, 2002).

Following the war, the CHP did not have a tolerance for nationalistic trends apart from the official/ Kemalist nationalism. In 1946, the change to a multiparty system and the Demokrat Parti (Democratic Party, DP) had been a hope for the Turkists. The DP's attempt to purge leftist groups pleased Turkists. Turkists became more organized at the beginning of the multiparty period. They gained supporters from young groups. The movement started to gain political acceptance within the society. It started to move towards an activist line. The socialist left was on the rise in Turkey in the same period. The Turkist movement gained effectiveness as a reactionary force against the socialist left (Uzun, 2005: 260-261).

The development of the Turkist-Turanist understanding, summed up to this point, was to leave both an intellectual legacy and a political/organizational cadre for the MHP. However, in spite of the intellectual and political accumulation, the Turkists were not able to establish a unified organization up to the end of the1960s. The representation of the unorganized and dispersed Turkist-Turanist movement by a political party took place upon the establishment of the MHP.

\section{Foundation of the MHP}

The root of the MHP is the Millet Partisi (Nation Party, MP). The MP was established in 1948 by the parliament members most of whom had left the Demokrat Parti (The Democrat Party, DP). Osman Bölükbaş1, one of the founders of the MP, established the Cumhuriyetçi Millet Partisi (Republican Nation Party, CMP) in 1954. The party was a populist, conservative nationalist rural middle class party in the 1950s. Previously established as the Türkiye Köylü Partisi (Peasants' Party of Turkey in May 19, 1952) it joined the CMP in 1958. The name of the party was changed to the Cumhuriyetçi Köylü Millet Partisi (Republican Peasants' Nation Party, CKMP). Its president Bölükbaşı resigned from the CKMP in 1962, and established the MP once more. Meanwhile, Colonel Alparslan Türkeş, 
who had been purged shortly after the 1960 coup d'état and had left the country with a foreign service, returned to Turkey in 1963. Türkeş and his circle joined the CKMP. At the assembly meeting held in 1965, Alparslan Türkeş was elected president. At the assembly meeting held in 1969, the name of the party was changed to the Milliyetçi Hareket Partisi (Nationalist Action Party, MHP). Following the leadership of Türkeş, the conservative discourse took a back seat and the ultra nationalist discourse loomed large in the party's ideology. (Arslan, 2002: 307).

\section{MHP Following the Coup d'état of September 12, 1980}

The coup d'état of September 12, 1980 was a turning point in the MHP's discourse. In the 1970s, MHP espoused the mission of advocating the flag, the nation and the country together with the state authorities. Thus, it had not expected to be seen as an "opponent" in a military intervention. However, with the coup d'état, the MHP was closed down (like all the other political parties). Türkeş and many party administrators were brought up for trial. Some were sentenced and many were tortured. Therefore, the coup d'état had been a "shocking" experience for the MHP. Being treated by the state in the same way as leftists/communists were treated, started a period of questioning among the MHP voters. An anti-system discourse emerged in patches and an organizational lacunae and disintegration was experienced in that period.

The Muhafazakâr Parti (Conservative Party, MP) was founded on July 7, 1983 as the continuation of the MHP. The party's name became the Milliyetçi Çalışma Partisi (Nationalist Working Party, MÇP) in 1985. In the assembly meeting of October 1987, Türkeş was elected the president of the party. This assembly meeting was also a turning point in the discourse and image of the MÇP/MHP. Academicians such as Devlet Bahçeli and Ali Güngör started to be influential in this period. Qualified cadres, a "scientific" discourse instead of agitative discourse, and a more professional determination of the policies were considered important. The historical framework, democracy, human rights and the rule of law were brought to forefront instead of defining an organic nation. As an alternative to all the imitation systems, the "domestic production" was brought up (Arıkan, 2002). Although the process of change had started, anti-Westernism was still an important issue of the 1980s.

There was a disagreement between the ones in favor of making a greater emphasis on Islam and the ones emphasizing Turkism. While the focus was on Turkishness in the Turkish-Islamic synthesis, it is more on Islam in the emergent view named "Turkish-Islamic idealism." The party administration was close to the state's official attitude that considered Islam a "motive." Therefore, the discrepancy between the party administration and the Turkish-Islamic idealists who had an Islamic discourse grew wider. The party was divided. Muhsin Yazıcıoğlu established the Büyük Birlik Partisi (Great Union Party, BBP) in 1992. In this way, the party was substantially separated from the Islamist group. This paved the way for a re-Turkisization of the MHP in the 1990s.

\section{The MHP in the 1990s}

In the 1990s, both the nationalist wave had risen and the MHP's change that began at the end of the 1980s had become evident. Developments in the world, and both Turkey's and the party's internal dynamics had been influenced by this. 
Globalization had brought about a new structuring in the world's economic and political life. The gap between the prosperous states of the "North" and the third world countries of the "South" had deepened. Turkey was taking its place between the North and the South in economic, cultural and social terms. Within this crystallizing hierarchy countries -including Turkey- were concerned about acquiring a prominent position for themselves. According to Bora (2004: 495-97), this atmosphere paved the way for the rise of radical nationalism since it enabled support for views which involved "militant" discourses directed at a higher position for the country. At the same time, the trends focusing on the national interests and producing radical solutions were gaining supporters. The MHP was already covering such discourses. It presented history as a struggle among nations with a discourse focusing on the upper/superior position of Turkey all along within this hierarchy.

The disintegration of the Soviets was another crucial development of the 1990s which affected the nationalist wave in Turkey and around the world. With this development, the West's superiority over the Communist Russia was recognized. This situation can be said to have refreshed MHP's selfconfidence. With the collapse of communism, the party started to proclaim that it was right in its yearslong struggle, and that its thesis of the collapse of communism had been affirmed. The nationalist movements rising in the Turkic communities provided the MHP with extra credit. The MHP headed towards gaining influence over that geography. Turkist motives started to get popular and to be more highlighted at the symbolic level (Arslan, 2002; Bora, 2004).

The MHP expressed its anti-Westernism by means of its anti-communist discourse. The ending of the threat of communism created a gap in the MHP's discourse. However, the MHP had always defined itself through an opposition to an existing or imagined enemy or "the other." Therefore instead of anti-Sovietism, already existing anti-Westernism started to be sharpened once more (Uzun, 2005). A growing inequity of income and the cumulative reaction among the wide masses devastated by globalization led to a result that generated hostility against the West (Yanardağ, 2002).

On the other hand, following the disintegration of the Soviet Union, the MHP needed to keep up with the changing conjuncture. In their program before 1990, liberalism, communism, Westernism and "imitation" were all unacceptable systems since they were not in conformity with the Turkish history and tradition. With a corporatist approach, the Turkish nation was seen as a whole. However, in the new era, this understanding was backward and outdated in a world of liberal-capitalist systems. Thus the party started to advocate a neo-liberal economy in its 1993 party program.

In this period, Turkey faced a new "wave of modernization.” Democracy was the dominant political theme. The MHP highlighted the Westernist nationalism in its discourse. Westernist Turkish nationalism was based on the assertion that 200-year complex of "backwardness" had now been overcome. It potentially had the idea or feeling of growing over its boundaries and imperialism. It emphasized a Turkey rising within its own territory (Yanardağ, 2002: 19).

One of the factors that was influential in the rise of the nationalist wave and in the prominence of the MHP's Turkist discourse in Turkey was the increase in terrorist events. A popular nationalism was pumped into the society with the rising PKK terror (Arıkan, 2002). The MHP had overstated loyalty to the military and the state in this period. It reproduced its unique mission of power, which advocated the indivisible unity of the country and the nation in reaction to the Kurdish problem (Yanardağ, 2002: 25). 
The popularization of nationalism and its prevalence in the general political atmosphere benefited the MHP. It headed towards being a mass party (Arıkan, 2002). From the beginning of the 1990s, it presented itself as a centrist, not a marginal, party.

However, the "moderation" in question added a completely contradictory, complicated and indecisive characteristic to the party's discourse. As can be seen, the traditional Turanist ideals, a racist understanding, the nervousness felt from "the other" and a sharpened anti-Westernism were intertwined with the 1990s' conformity to the changing conditions, to an articulation of the process of globalization as a leader country, and an emphasis on the Westernist values such as democracy and human rights. This renders it hard to analyze the MHP. In the following chapters, the extent to which the party's discourse on the EU coincides with the picture introduced above will be analyzed.

\section{THE EU AND THE MHP: THE IMAGE OF THE EU IN THE DISCOURSE OF THE MHP}

The Ottomans' perception and characterization of the Europe/West had also varied. The perception of the West for the Ottomans had been religion-oriented for a long while. However, the perception in question began to change with the start of the decline of the Empire. Hanioğlu points out that the idea of reshaping the Ottoman State in accordance with the West was the most critical point in the Ottoman/ Turkish history of thought (1989: 16). The formulation of "being like the West," which was first seen as "the remedy for getting over the crisis" and as a technical/military issue, had started to surround social and cultural living spaces. Hanioğlu (1989: 16) points out that the idea of reshaping the Ottoman State in accordance with the West was the most critical point in the Ottoman/Turkish history of thought. Here the important thing was the acceptance of the ideas that the West was advanced, that it had desirable and long-awaited characteristics, and that the Ottoman Empire was lacking and backward compared to it. On the other hand, there was an effort to adopt the technological developments but not the cultural values of the West. There was a concern about the damaging influences of Western culture on the local culture. Consequently, the West was a subject "that involved corrupting influences within its differences;" and thus, it should be approached with deliberation. This kind of a perception of the West had also been very effective following the establishment of the Republic.

The European Union was a new phase in Turkey's relations with the West and its Westernization adventure. Turkey's relations with the European Union have a history of almost fifty years. This process, which can be considered long, has witnessed different perceptions of the European Union.

This is also similar in terms of the MHP's perceptions, which became one of the prominent actors in the Turkish politics from the 1970s onward. In the 1970s "Turkism," coming into prominence in the MHP's ideology, targeted Western influence and "Westernist" approaches inside the country; and it adopted a "turn to yourself" discourse against Westernization policies, starting with the Tanzimat (Reform) Era of the Ottoman Empire" (Özdoğan, 2002: 10). In the same period, the MHP's discourse on the European Union (its name was the European Economic Community at that time) had a similar character.

In this period the MHP defined the EU as "an economic organization." However, the EU, appearing in the party's discourse as an economic organization which could be joined, was turning out to be a dangerous structure when the cultural and political components were considered (1973; 1977). Türkeş 
expresses this clearly in the "Milliyetçi Hareketin El Kitabl" ("Manual of Nationalist Movement"), which was first published in 1973, then again in 1977 by the party: “... [the] MHP commits itself to the use of regional economic organizations as a means of social, cultural and political integration going beyond the economic relations." This statement asserts that the EU was discussed in two different axes, namely, the material/technological/economic and the spiritual/cultural/civilizational. This is a division that was referred to quite often in debates on the West.

The perception of "the West as a corrupting civilization" was the fundamental reason for the harm that Türkeş saw in "social and cultural" integration. As a matter of fact, Türkeş also added:

[The] MHP is openly and absolutely against the Common Market because it will cause an indirect implementation of the Treaty of Sevrès by allowing foreigners to acquire land and opportunities in any part of the country and as much as they want; it will lead to cultural and social deformation; and it will prevent the development of national industry [emphasis added] (MHP, 1973; 1977: 43).

The reason why Türkeş was doubtful of political integration was that he saw the EU as an indirect enforcement of the Treaty of Sevrès. Here it should be noted that in the MHP language the EU was presented as "an obvious enemy, secretly aiming to destroy Turkey's territorial integrity" through discussing the relations with the EU in a framework referring to the Treaty of Sevrès. The parties to the Treaty of Sevrès were the Ottoman Empire and the Allied Powers with whom it had fought for a long while. In this context, the EU was seen as a continuation of the Allied Powers that had tried to seize lands of the Ottoman Empire, rather than an economic organization undertaking the regulation of some political and social elements.

Despite the dark picture outlined above, it is also noteworthy that the MHP could not leave the EU aside completely.

Our government is a coalition government [The Second Nationalist Front Government, together with the Adalet Partisi/AP (Justice Party) and the Milli Selamet Partisi/MSP (National Salvation Party)]. In the protocol of the coalition, which is a consensus government, our opinions about the Common Market are determined. Accordingly, necessity of a regulation and reform based on mutual interests, particularly Turkey's industrialization matter, was manifested. Today our governments are also working for this (Nalbantoğlu, 1994: 200-201).

The year 1978 witnessed the beginning of an uncertain period in terms of Turkey-European Union relations. Turkey demanded to be released from its obligations in 1978. Following the coup d'état of September $12^{\text {th }}, 1980$, the relations were suspended. An atmosphere of military intervention and the following interruption in the relations removed the EU from the agenda. Turkey applied for membership on April $14^{\text {th }} 1987$ but this application was rejected in 1989. The relations, passing through a period of stagnation until the year 1995, revived with the enactment of the Customs Union Treaty in 1996. However they were interrupted again after the Luxembourg Summit in 1997. 
According to the MHP, which was the government party when the Customs Union Treaty was signed between Turkey and the EU, from this date onwards the EU had become an "unfair" party by blocking the required financial aid to Turkey. In addition, the EU enlargement was decided at the Luxembourg Summit in 1997; and the accession of eleven countries that had applied much later than Turkey was accepted. Therefore, the EU was a party "excluding Turkey from the process" and "discriminating" against Turkey, and "set[ting] it [in] a secondary position which is not in the United Europe but kept it along its trajectory." (Bahçeli, 2002b: 16-19).

At the EU Summit that was held in Helsinki in December 1999 when the MHP was also a partner in the coalition government, the Union accepted Turkey's candidacy. This development led to a period in which the government partner MHP's discourse on the EU was swayed toward different points. The MHP started to avoid explicitly highlighting the image of an "enemy" while mentioning the EU. On the contrary, the EU (having accepted Turkey's candidacy) turned out to be a subject "accepting gradually increasing international reputation and power of our country," "rediscovering its geopolitical and geoeconomic importance that was underestimated in the post Cold War period," and "needing Turkey for desired stability in the Caucasus, the Balkans and the Middle East." (Bahçeli, 1999d) Similarly the EU offered Turkey a "route map" which was "free from prejudices and additional conditions to a certain extent compared to the past." Rather than "impositions," "disturbing" points existed related to some issues (Bahçeli, 1999d). In a sense, the EU was portrayed as a party acknowledging its mistake and accepting the facts related to Turkey. However, the EU still continued to be a "suspicious" subject in the MHP's discourse.

After 1999, the EU was "addressed as a party" from whom an "amicable" approach, "good will," "sincerity" and "tolerance" were expected. The relation with the EU was not a simple relationship based on interest but rather "a strategic and economic association."

The EU, having been turned into an enemy by the MHP in the 1970s, at the end of the 1990s and right at the beginning of the 2000s it was portrayed more as a partner having some negative characteristics. A "complaining" tone was more dominant in the discourse. In this narrative, the EU's negative characteristics were presented in the form of defects such as "not being freed from prejudices" and "being confused" rather than hostile (Bahçeli, 2000d).

"Disappointment" was one of the prominent themes especially in the texts emerging right before the November 2002 elections. Two functions of the theme of disappointment can be pointed out. First of all, this theme of disappointment indicated that what was required was accomplished in the period when the MHP was a coalition partner. This meant that the party had no responsibility for the stagnation in the relations; and all the responsibility belonged to the EU, which could not get rid of its "ulterior motive." Secondly, the theme of disappointment meant a "transition" within the process leading to the MHP's construction of a completely negative image of the EU in the future because the EU, which had been disappointing and "offending" Turkey at the beginning, would gradually have an image as if it were deliberately working against Turkey.

By the year 2003, in the MHP's texts the EU was constructed through an image of "enemy" in an unassailable manner. It was again identified with a historical enemy who had been fought against during the long Ottoman/Turkish history. Included in this perception, the EU was "the ones who want to realize the dreams of [the] Byzantine Empire" (Bahçeli, 2003b). 
In the MHP's discourse, in addition to constructing the EU as the enemy, there was also an increasing elaboration of the enemy's characteristics. The EU was a compelling and even censorious institution that imposed conditions on Turkey. Furthermore, it had both transparent and ulterior motives: it wanted Turkey "to pay a price," it approached Turkey with "double standards and exclusion," it aimed "to control Turkey," and it wanted "to conquer" Turkey (MHP, 2004a; MHP, 2005; 2006a). This meant that it led Turkey to catastrophe and a "blind alley" (in collaboration with the country's government). It expected Turkey to enter into "a way whose end and length was uncertain," it ordered that Turkey "met the instructions in all the reports," it "extracted compromises from Turkey," and implied that "there was no return from these compromises." That is, it ventured directly against Turkey's independence and its integrity. Finally, the EU appeared as "an imaginary goal" and a "lie" (MHP, 2006a).

\section{THE POSITION OF TURKEY AND THE RELATIONS IN THE DISCOURSE OF THE MHP}

The year 1999 signifies a quite critical year in the MHP's perception of EU-Turkey relations. According to Bahçeli, in the period from 1959 to the 2000s, relations were "bumpy," "distressed" and full of "disappointment." "Stagnation," "unevenness" and "breaks" were the other features of this period. In this duration, a significant "acceleration" could not be brought into the relations. Besides this, Turkey was the party that made sacrifices. It had been given a secondary position on the EU's orbit. The negation in this narration, basically, served to underline the progress which, it emphasized, had to be realized in 1999. Indeed, according to the narrative of the MHP, in this negativity a change of destiny was realized in 1999.

Thus the beginning of the 2000s was the period when the MHP indicated that Turkey needed to take part in the global institutions: Turkey should not withdraw into itself; it should not be outside the process of globalization. Accordingly; the relations with EU were seen as a tool for Turkey to catch up with the global developments.

In this period, another point in the regard to the MHP attitude toward EU-Turkey relations is worthy of mention. These emphasized that EU-Turkey relations would be carried out alongside Turkey's relations with its eastern neighbors. It was evidence of the concern of a party that had built its rhetoric for a long time on the opposition to the West/EU. By associating itself with the Turkic Republics, it was trying not to frighten its base.

However, the "affirmative" stance towards the structure of EU-Turkey relations in MHP's rhetoric was not prolonged. Immediately from 2003 onwards, the rhetoric again acquired a negative character. It emphasized that the membership in the EU that had been transformed to a state policy had not been examined in every phase and that the process could not go beyond the "one sided dependency relation" (Bahçeli, 2003c: 26).

From the middle of the 2000s in the MHP's discourse, EU-Turkey relations were viewed as essentially a "dependency-satellite relation," and characterized as "the story of inability," "deception-distraction process" and even "a buffoonery" (MHP, 2006b: 3, 41). According to Bahçeli, it was "a very dangerous submission process" (2006a). 
In the narration of the MHP, the relations with the EU were handled in the framework of the "situation that Turkey falls into/or is thrown into." The emphasis of the superior and advanced country in the perception of the MHP and its reporting regarding Turkey's position in its relation with the EU exposed a tension. In the language of the MHP in general, along with that relation, Turkey was portrayed as duped, detained, wronged and subject to a double standard.

However, the transition from 1999 to 2000 prepared a suitable ground for MHP's narration concerning a Turkey that would become the "leading country." The year 2000 was characterized as the "closing of an age" (Bahçeli, 2000g), "a historical turning point, the beginning of a new era and an era of change" (Bahçeli, 2000h). The Turkish nation would again find its place that it deserved by fulfilling the requirements of the new age.

In these narrations Turkey emerged as a country that took its power from its history and would carry this power into the new age. Bahçeli (1999a) stated that the MHP's target of being the leading country was "to construct a strong and active Turkey that had been opened to the world through protecting its national identity and honor."

The Helsinki Summit in 1999 pointed out an explicit progress in the position of Turkey. Thus, Bahçeli, in this summit, stated that Turkey had been accepted as a candidate to the EU with unanimity and under the same conditions with the other candidate countries (Bahçeli, 2000g). The MHP suggested that "to be the ascendant nation" which was one of the most important components of the MHP's rhetoric, did not represent a contradiction to Turkey's candidacy to the EU when it was a part of the coalition government. While the Party indicated that it was in line with the developments required by the new age, it also emphasized that it had not drawn away from its traditional goals (Bahçeli, 2000g).

However, the "affirmative" regard was not prolonged. By the year 2002 Turkey was presented as the country whose sovereignty had been weakened in the process. This narration of the MHP contained the problem of "a concern of honor" rather than a fear of the delegation of authority. In other words, each and every point limiting the national sovereignty was sentimentalized as a loss of honor.

The MHP underlined that Turkey not only in its foreign policies but also in some fields inside its borders would incur losses of sovereignty:

The understanding which is put forward with the Negotiation Framework Document will bring the result of the transfer of all of Turkey's policies, decisions, and in time relinquish all administration to EU control. A Turkey that EU inspectors and EU missionaries govern was the aim. This situation would be the DÜYUN-U UMUMI IDARESI (MHP, 2006b: 29).

In the vocabulary of the MHP it is meaningful to remember Düyun-u Umumi Idaresi, from the Lausanne and Montreux Treaties. Düyun- и Umumi terminated the independence of the Ottoman Empire. The expressions of those treaties emphasized what was gained with the Independence War. Thus, the sovereignty which had been gained against the enemy would be lost with the accession process to the EU. 
According to the MHP, the EU expected Turkey to radically change all of its regulations with respect to its national security and to give up the indivisible integrity of the country (MHP, 2005). Besides, the EU demanded that Turkey come to a compromise with the PKK (MHP, 2006b). The MHP emphasized the connection of the EU and the PKK: "What the EU demanded from Turkey persistently in the name of the alignment with the Copenhagen political criteria and the claims of the PKK/KADEK overlap" (Bahçeli, 2002b: 51, 52).

Another point that needs to be mentioned about the perception of the MHP was the enormous glorification of the geographical location of Turkey: “... one of the most problematic and favorite regions of the world is Eurasia, and Turkey takes part in the point of the triangulation of Eurasia" (Bahçeli, 2000f: 26). It emphasized frequently that Turkey was the most important country and the center of the most complicated geography of the earth.

The emphasis on the geo-strategic location of Turkey bore the allusion that its territories were desired by "others." In fact this glorification referred to the existence of the enemies who sought to splinter other territories.

While the MHP portrayed Turkey's position even more seriously, in fact it emphasized the need for a rebirth. The Independence War was conspicuous in the speeches of Bahçeli prior to the 2007 elections. The Independence War pointed to the birth of the Turkish Republic. The Turkish people gained their independence in a period when they were faced with the danger of losing their sovereignty. In the rhetoric of the MHP, Turkey was face to face with a new sovereignty/independence problem this time. Thus, it needed a new struggle for rebirth. The country would come to life again as a leader (of course with the leadership of the MHP).

\section{DOMESTIC ATMOSPHERE FOR THE EU IN THE DISCOURSE OF THE MHP}

\section{Threat for National Unity}

In the discourse of the MHP, one of the most important points that never changed since Türkeş was the definition of the nation. According to this, only one nation existed in Turkey. The whole nation was "brothers and sisters of each other, all belonged to the same religion; all were the community of the same almighty prophet, possessor of the same sacred book, and the same flag, children of the same country, the people of the same state." With these characteristics "our nation was a sacred whole who did not accept division" (Türkeş, 1979: 17).

According to this, to mention the existence of any ethnic or sectarian difference inside the country was considered dangerous for the unity of the country. Consequently, the problems which were defined on the basis of ethnicity were characterized as incitements of the foreign centers that threatened to break the unity of the country.

In the party's discourse, although the national unity approach and those who sparked criticism against national unity had changed, the expressions regarding their aims and their methods remained generally the same. It was clear that in the MHP's narrative from the end of the 1990s and beginning in the 2000s onwards, the institution that threatened the national unity and integrity was the EU. In the 
discourse of the MHP, the threat of the EU process towards Turkey's national unity was part of the "democratization" criteria of the Union.

For the MHP, on the one hand democracy and human rights were exalted as the values which needed to be developed. On the other hand, these values were mentioned with their potential to form a base which would lead the country into difficulties. According to narratives of the MHP, these values were mostly used as symbols, and under these titles other political struggles are carried out. (Bahçeli, 1999c). The EU process paved the way for "detrimental" constitutions that made use of the concepts of democratization and human rights. The democratization criteria had the characteristics of supporting PKK terrorism. In the narration of the party, the support of the EU for the politicization process of the PKK occupied a dominant place.

According to Bahçeli, the EU was confused about the concepts of human rights, terror, democracy and racism. Some of the components inside the EU were unable to make a differentiation between democratization and terrorism (Bahçeli, 2000a). Depending on the subject that was emphasized in the party's discourse, some of the EU countries protected the terrorist organizations that were the enemies of Turkey and aimed to damage the national unity. The EU used the notion of the human rights as an excuse for this.

The MHP saw another important dimension of the EU process in the threat of breaking down Turkey's national unity-integrity. According to this, the EU again, by using the democratization and the human rights concepts, supported ethnic discrimination. In the discourse of the Party, the EU's support for terrorism and the minority question were the two dimensions of breaking the national unity-integrity. However, in the discourse of the Party these two dimensions (minorities and terrorism) were mixed with each other. Subsequently, the matters related to democratization and human rights (the minority question was also discussed under these titles) would easily be associated with terror and division. For instance, basically the issue of minority rights that was discussed concerning the Kurdish question and education in the mother tongue which was included with these rights, took place as the "new game of the terrorist organization" (Bahçeli, 2002a) in the discourse of the MHP. The demands regarding the language, on the other hand, prepared a ground for the identity of "Türkiyelilik" ("Turkeyness") (Bahçeli, 2005). The Türkiyelilik identity damaged the sense of belonging to one nation. The concept of self-determination that would lead to division was one of the impositions proposed to Turkey in the EU accession process. Besides, it was presented as a cultural right.

The demands of the EU which were bound to divide Turkey covered not only the ethnic minorities but also the religious minorities. Therefore the division of Turkey was discussed not only on the ethnic basis but also on the religion basis in the discourse of the MHP in the EU process.

Bahçeli (2005) noted that the EU asserted that apart from Sunni Islam in Turkey, other religions and sects do not have the freedom of worship. The danger that was imminent here was the possibility of the recognition of the Armenian, Greek and Jewish communities as legal entitlements. The members of these three communities would be entitled to own real estate. The waqfs, legal charitable foundations, belonging to these communities would not be subject to legal supervision. There would be a new administrative regulation for the Armenian community. 


\section{“OTHERS” AND THE MHP ITSELF IN THE MHP'S DISCOURSE ON THE EU}

\section{The MHP}

"The MHP Protecting the Country in a Self-Sacrificing Way." As indicated in the discourse of the MHP, globalization was on the one hand a process that should be entered to become an active (leading) country. However, on the other hand, the Party's discourse drew attention to the tension between taking part in the process and avoiding the process.

In the discourse of the MHP, the 1990s, when the globalization process made us feel its effects, was a troubled period for Turkey. Besides the EU issue, the country was passing through a hard period inside and out. As noted before, in the discourse of the MHP the $21^{\text {st }}$ century was seen as a new but a formidable beginning. In this beginning the MHP assigned itself the following mission:

Today the very first historical task for us is to give this sacred country spotlessly to the next generations because this country is a treasure that is consigned to us. Therefore to give this trust with all of its beauties, with its national and moral wealth to next generations is the duty of all of us, the duty of everybody. In truth, this is the fundamental goal and basic duty of the existence of the ülkü ocaklart. Therefore, it owns a very almighty, very honorable, very meaningful mission (Bahçeli, 2000b).

Basically, the mission that the MHP assigned itself was the continuation of the positioning style of Turkey in its history. In the discourse of the MHP, "to protect the country in a self-sacrificing way" was one of the leading themes. According to this and thanks to the efforts of the Turkish nationalists, the hard and miserable periods of Turkish history were over. In the darker periods of the Turkish history, the ülkücüler (those who supported the ülkü ocaklarl) also passed the tests together with the country. (Bahçeli, 2000c). The MHP presented itself as the continuation of the group who started and carried out the Independence War (Bahçeli 1999b). In the MHP's discourse the Turkish nationalists were constructed as those who were "aware of their national duties and responsibilities" (Bahçeli, 2000c).

The MHP emphasized that, as in any period of history, in the $21^{\text {st }}$ century the MHP would be aware of its mission and responsibilities. The existence of the MHP was identified with the continuation of Turkey. In the party's discourse, the MHP was portrayed as protecting Turkey from every danger. In this narration, while the country was losing its independence, those who would protect it were the Nationalists and the MHP. The MHP increasingly intensified the theme of "struggling on the point of protecting the country." This was a struggle which was to be carried out with the leadership of the MHP with a call to the Turkish nation:

The Nationalist Action will resist the darkening of Turkey's future with all its conditions and with democratic ways; it will do all its duties regarding the struggle to protect Turkey's unity, honor and pride; and will be the standard-bearer of this blessed struggle.... We invite all our citizens who love their country and nation to take part in this struggle. (MHP, 2004b; Bahçeli, 2007c). 
The MHP assigned itself one more mission in the EU process, that of telling the truths to the nation. In the MHP's discourse, “... [the] EU process to conceal the truths from people" is an important theme (Bahçeli, 2000e). According to Bahçeli, the ability of the people to sufficiently perceive the threats that the country is facing is hindered; blackout campaigns are being performed. (Bahçeli, 2003d: 8; MHP, 2006b). At this point, the MHP constructs itself as a subject that realizes and shows the truths to everybody, and warns everybody as well (Bahçeli, 2003a).

"MHP Supporting the EU Membership "With All Its Heart" / "MHP as Accused of being the Opponent of the EU." In the EU context, the self-sacrificing narration of the MHP was constructed in various ways. One of the frameworks that the self-sacrificing narration established was the MHP's "endurance for being presented as the opponent of the EU while it was crying out the truths."

As indicated before, the MHP's approach to the EU contained ambiguities and contradictions. The most important break within the Party's approach to the EU materialized in 1990s onwards. The MHP's support of the EU membership, especially when it was in the coalition, was one of the points appearing frequently in its discourse. According to Bahçeli, the developments that were achieved during the EU process in a great portion was a result of the MHP's decisiveness. Compared to the progress that was made in all the 40 years of relations with EU, more progress was made between 1999 and 2002 (Bahçeli, 2002b). However, on the other hand the MHP also expressed "the threats" that had been pointed out before. At this point the MHP stated that to express the national sensitivity led to being perceived as an EU opponent. Therefore, the MHP presented itself frequently as the sincere supporter of the EU. It stated that the Party "cared" and "took the full membership process seriously" before everything else (Bahçeli, 2000c). The EU was shown as one of the basic and leading targets of Turkey and it emphasized that the MHP supported the membership sincerely (Bahçeli, 2002b: 1, 9, 24). According to Bahçeli, the expressions of the MHP regarding the national sensitivities did not express an opposition to the EU. "On the contrary, this was the proof of stating honestly and clearly (the terms of) healthy relations with the EU and the full membership" (Bahçeli, 2002b: 62). The MHP justified its support for the EU as a requirement of the national interests.

The MHP emphasized that it denied the accusations of being an opponent of the EU. In this narrative, the reason for supporting and not being against the EU was due to a consideration of the country's interests. Indeed, the MHP "took the interests of Turkey before everything" (Bahçeli, 2002b: 124). Its target was "to provide the actualization of Turkey's integration with Europe by a sincere and selfrespecting cooperation process, and to ensure that Turkey take the place in the EU which it deserved as an honorable member" (Bahçeli, 2002b: 10).

This narrative enabled the MHP to characterize itself with qualities of "heroism/boldness," and advocating the truths at the expense of being presented as the EU opponent. Parallel to this, Bahçeli stated that they would not give up debating the EU's policies toward Turkey and they would not abandon what they knew as truth due to the malevolent campaigns (Bahçeli, 2002b: 132).

This type of narrative was more explicit in the period when the party was in power. In this period when both the negative characteristics of the EU and the positive ones were mentioned, the MHP especially emphasized that it was not against the EU. However in the party's discourse, along with the construction of the EU as an enemy, this emphasis became blurred. 


\section{"The Others"}

"Those Who Underestimate Sensitivities of the MHP" / "Those Who Ease the Job of the Enemy." In the party's discourse there was a focus on a systematic campaign against the MHP concerning the EU. Those who carried out the campaign against the MHP were some of the media, civil society organizations and some political forums. According to Bahçeli, the forums mentioned trying to present the right and legitimate sensitivities of the MHP as unimportant. They underestimated the MHP's EU approach with metaphors like "the Syndrome of Sevrès" "the paranoia of the division" and "the paranoia of change" (Bahçeli, 2002b: 25). According to Bahçeli these "warped mentalities" were annoyed by the expression of "Turkey's national honor and interest" that the MHP valued (Bahçeli, 2000e).

In the language of the Party, criticizing the MHP's approach to the EU was identified with disregarding the national interests. The ideas of actors apart from the MHP within the country were characterized as "mentality shift," "meaning shift." Consequently, it implied that the criticisms were too "unhealthy" to take into account.

In the MHP's discourse those who facilitated the job of the enemy (especially mentioned was the political party in power) basically were presented as "the toys of those who want to realize the dreams of Byzantium" (Bahçeli, 2003e: 19). The story of the interior "traitors" who supported the foreign enemy, in the narration aggravated the country's condition even more. The emphasis put on the seriousness of the country's situation signified the urgency for a solution. Consequently, the MHP presented itself as a protector whose predominance was an urgent matter.

"The Submissive Mentality" and "West-admirers." In the discourse of the MHP the "submissive mentality theme" which accepted the EU membership without questioning Turkey's situation/losses was used frequently. This submissive mentality caused the EU matter to be discussed on a narrow and shallow ground. (Bahçeli, 2002b: 9, 25; Bahçeli, 2003c: 28-30). Therefore, it impeded the discussion of the matter of the EU in a healthy environment. Consequently, it claimed that the reason why the MHP encountered unjust accusations was this mentality.

The contradiction between the MHP/nationalists who protected the country versus the submissive others was established. Basically, in the MHP's discourse the emphasis on submission was meaningful. The "submissive mentality" in the MHP's discourse was employed to evoke the behavior of the last period of Ottoman governments/sultan that led the country to the collapse. Indeed, in the official narration of history, the theme was common that the "Ottoman Sultan submitted the country to the foreigners." Therefore, the narration of the submissive government versus the nationalists who carried out the independence struggle was reproduced in the EU context. Another striking point was that the MHP did not clearly spell out who was referred to by the submissive mentality in the period when the Party was in power. However, in the AKP period, the one pointed out by "the submissive mentality/ milieus" was more obviously the AKP government (Bahçeli, 2003d: 8, 25, 27).

In the MHP's discourse Western admiration "reached a mentality that had problems with national unity, national identity and national values" (Bahçeli, 2007a). This was a mentality that conflicted with national values; it would become a "love of the foreigner" (Bahçeli, 2007b; Bahçeli, 2007c) (the MHP put the "love of Turkey" -- "Türkiye Sevdalıst -- against this). 
The narration shows that the MHP constructed itself as the only protector of the existence and unity of the country. The MHP positioned itself against the "Western admirers." Therefore, it constructed itself as the subject who also protected the "core culture" of the nation. What was emphasized was that, along with the very existence of the country, the assurance of the moral values of the nation belonged to the MHP.

\section{CONCLUSION}

To sum up, the MHP's perception of the EU has varied over the course of time while at the same time contradictory aspects coexisted in this discourse. In the 1970s, the party characterized the EU as "an economic organization" and considered it "harmful" in social and cultural terms. Following the signature of the Customs Union Treaty, the level of negativity increased in the discourse. This completely negative discourse changed as Turkey's candidacy to the EU membership was realized in 1999 when the MHP was a partner in the coalition government. In the 2000s, the EU's negative aspects started to be mentioned in addition to its positive aspects. The MHP brought the theme of "disappointment" to the forefront related to the EU before the November 2002 elections. The party which lost its seat in the parliament as a result of the November 2002 elections, adopted a very aggressive discourse related to the EU.

A similar course of events can be seen in the perception of EU-Turkey relations and in the perception related to Turkey's position in these relations. In the period before the 1999 Helsinki Summit (that is, the period before MHP was a government party), the MHP had stated that the relations were stagnant and negative. A "change in the destiny" was achieved in the year 1999 when the relations had attained an "equitable" nature. However, this discourse did not last for long. With the AKP government, the MHP started to emphasize that the relations turned into a one-sided dependency relationship. In this picture, Turkey was gradually portrayed in a more passive position. At this point, hurting Turkey's pride came up as an important theme. MHP often referred to the War of Independence and thus transmitted the message that Turkey was occupied in a sense. There was the danger that such a discourse could be used as a justification for more aggressive nationalisms. Legitimizing the use of violence by the cause of "defending the country" could catalyze the aggressiveness of the masses.

The MHP also combined the influence of the EU process in the domestic atmosphere with a similar theme of "threat." The EU process threatened two things especially: national integrity and national identity. The EU did that implicitly through supporting terrorism and highlighting ethnic and religious minorities. In the party's discourse, the matter of ethnic minorities was already considered a ground for terrorism. The issues of terrorism and minorities could not be separated from each other. According to the MHP, highlighting the minorities (especially the ethnic minorities) was a long standing method used by those who want to split Turkey apart. They indicated that a similar method had also been used in the 1970s by the supporters of a foreign ideology (Marxism). By the 2000s this method was applied using concepts like human rights, minority rights, cultural rights and democratization. Therefore, these concepts were always approached with suspicion by the party. It is worrisome that a political party that has decision making authority approaches these concepts which are crucial in the democratization of a country with this kind of a suspicion.

While the MHP presented the state of Turkey-EU relations from a negative perspective, at the same time, it stressed the need for a rescuer. It invited people to take part in this movement to save the 
country. It also attributed some characteristics to the ones in the "opposing front." According to the MHP, these actors had a tendency to surrender. They admired the West; they blocked the development of a healthy debate on the issue, and they carried the issue for debate on a limited and superficial platform.

The worries uttered by the party around the EU framework were related to the points which were discussed in a broader framework by some thinkers (especially hyperglobalists) as being eroded through the globalization process as the transfer of the nation-state's sovereignty in the political field, and the threat of national cultures in the socio-cultural field. Similar to the discourse of the skeptics, the MHP also stated that, in the globalization era, nation-states and nationalism would not only remain important but would also gain power gradually. Nationalism was seen as the best adhesive within the changing order due to globalization. It was offered as a protective thought within the chaos of the new order. The MHP's discourse on the EU pointed out a field where the worldwide tension between globalization and nation-state/nationalism was materialized in the context of Turkey.

The party's discourse on the EU has also been shaped by its traditional structure. The MHP's themes such as a fear of foreigners, the perception of a continuous threat, a claim of being the real possessor of the state, nation (and its values), the approaches inherent in the party's discourse throughout its history, can also be observed in the issue of the EU.

Some views show that the MHP experienced a kind of "moderation" since the 1990s. This "change" can be traced in the context of the EU. In this period, the MHP occasionally stated that to be included in the EU was necessary for strategic reasons. However, the actual influence of the mentioned "change" on the discourse was to render it quite complicated and contradictory. As a matter of fact, despite all the negative/fierce approach, the MHP did not express its opposition to Turkey's EU membership in an open and clear manner. On the contrary, it complained about appearing/being depicted as if it were against the EU. On the one hand, it complained that globalization and the EU served to politicize the minorities. Therefore, there was a phenomenon whose influences should be avoided. On the other hand, it emphasized the necessity of getting involved in this process as a requirement of the new era. This articulation required "compromise" in terms of the points that the party highlighted as "national sensitivities." Consequently, the party's discourse exhibited an uncertain and contradictory structure due to staying in between. The MHP tried to overcome this "crisis" by means of highlighting its position as the "leading country" in the process. There would be an involvement in the process but the "greatness" of Turkey would not be compromised. In this way, the MHP transmitted the required message to its voters while at the same time trying to save itself from being regarded backward.

In the dark picture outlined in the MHP's discourse on the EU, the year 1999 looks like a "salient point." Only the Helsinki Summit held in the period when the MHP was in power could be assessed as a positive step by the party. On the one hand, the MHP legitimized this on the basis of keeping up with the era; and on the other hand, it explained that the National Programme, signed in the framework of adaptation to the European Union when it was a government party, involved hard conditions.

On the other hand, the party can not be said to adopt a positive discourse related to the EU during the whole period when it was a government party (between 1999 and 2002). Shortly after Turkey's becoming a candidate country, it again started to portray the EU in negative terms although not very severely. This situation could partly be said to be related to the dynamics of domestic politics and that the MHP's anti-EU attitude aimed to oppose the Anavatan Partisi (Motherland Party, ANAP), one of 
the coalition partners which pursued a pro-EU policy in that period. Today as well, the MHP uses the EU issue as a means of opposition to the government party. The pessimism of the picture portrayed related to the EU creates a suitable condition in order to criticize the AKP government that pursues a pro-EU policy.

Of course, accession to the EU has been a painful process for many countries. Every country has gone through debates involving tensions and uncertainties within the framework of their domestic conditions. Turkey has been discussing the issue within the framework of its own historical, political and cultural conditions. It is also useful that the critical points uttered by the MHP have been discussed. However, a discourse focusing on "enemy" and "collaborationist domestic betrayers" can lead to the danger of approaching every call for recognition of identity from this perspective. Moreover, the discourse in question blocks a multi-dimensional argumentation of the issue.

\section{REFERENCES}

Akçam, T. (1995). Türk Ulusal Kimliği ve Ermeni Sorunu (Turkish National Identity and the Armenian Question). İstanbul: İletişim.

Arıkan, B. (2002). “Türkeş’ten Bahçeli’ye MHP: Değişim Nereye Kadar? (The MHP from Türkeş to Bahçeli: What Is the Extent of Change?)," in S. Öngider, (ed.), Milliyetçilik, Faşizm ve MHP (Nationalism, Fascism and MHP): 39-70. İstanbul: Aykırı Güncel.

Arslan, E. (2002). “Faşizmin Siyaseti: MHP’nin İktidar Bloğu Karşısında Değişen Strateji ve Konumları (The Politics of Fascism: The MHP's Changing Strategies and Positions against Government Block)," Praksis (5): 302.

Bayraktutan, Y. (1996). Türk Fikir Tarihinde Modernleşme, Milliyetçilik ve Türk Ocakları (Modernization, Nationalism and "The Türk Ocakları" in Turkish Intellectual History). Ankara: Kültür Bakanlığı.

Beck, U. (1999). The Reinvention of Politics. (Siyasallı̆̆ın İcad1). (Trans. Nihat Ülner) İstanbul: İletişim.

Bora, T. and Can, K. (2004). Devlet ve Kuzgun: 1990'lardan 2000'lere MHP (State and Raven: The

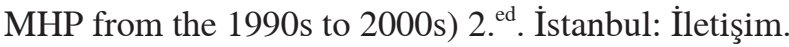

Çalık, M. (1995). Siyasi Kültür ve Sosyolojinin Bazı Kaynakları Açısından MHP Hareketinin Kaynaklart ve Gelişimi (1965-1980) [The Resources and Development of the Movement of the MHP in terms of Some Resources of Political Culture and Sociology (1965-1980)]. Ankara: Cedit.

Erbaş, H. (2000) “Küreselleşme ve Ulus-devletin Aşınımı Sürecinde Toplumsal Eşitlik/Adalet (Social Equality/Justice in the Process of Globalization and the Erosion of Nation-state)." Doğu Batı. (13): 213-224.

Gelekçi, C. (2003). Küreselleşme ve Milli Kültür (Globalization and National Culture). Unpublished Ph.D. thesis. Ankara: Hacettepe University, Faculty of Social Sciences. 
Hall, S. (1998). "The Local and the Global: Globalization and Ethnicity (Yerel ve Küresel: Küreselleşme ve Etniklik)," in A.D. King (ed.), Culture, Globalization and the World-System (Kültür, Küreselleşme ve Dünya Sistemi): 39-61 (trans. Hakan Tuncel), Ankara: Bilim Sanat.

Hanioğlu, Ş. (1989). Osmanlı Itttihad ve Terakki Cemiyeti ve Jön Türklük. Cilt: 1. (The Committee of Union and Progress and Young Turkism) (1889-1902). İstanbul: İletişim.

Keyman, F. and Sarıbay, A.Y. (1998). "Giriş: Küreselleşme, Siyaset ve Toplumsal Yaşam (Introduction: Globalization, Politics and Social Life)," in F. Keyman and A.Y. Sarıbay (eds.), Küreselleşme, Sivil Toplum ve İslam (Globalization, Civil Society and Islam): 9 -13. Ankara: Vadi.

Mackay, H. (2000). "The Globalization of Culture," in D. Held (ed.), An Introduction to the Social Sciences Understanding Social Change, a Globalizing World? Culture, Economics, Politics: 47-84. London and New York: The Open University.

McGrew, A. (2000). "Power Shift: From National Government to Global Governance," in D. Held (ed.), An Introduction to the Social Sciences Understanding Social Change, a Globalizing World? Culture, Economics, Politics: 127-167. London and New York: The Open University.

Nalbantoğlu, M. (1994). Alparslan Türkeş ile Tarihi Aydınlatan Sohbetler (Conversations with Alparslan Türkeş that Illuminate History). İstanbul: Hamle.

Öğün, S.S. (1992). Türkiye’de Cemaatçi Milliyetçilik ve Nurettin Topçu (Communitarian Nationalism in Turkey and Nurettin Topçu). İstanbul: Dergâh.

Özdoğan, G.G. (2002) “Turan”dan “Bozkurt”a: Tek Parti Döneminde Türkçülük (1931-1946) [From "Turan” to "Bozkurt": Turkism in a One-Party Era (1931-1946)]. İstanbul: İletişim.

Özkırımlı, U. (2008). Milliyetçilik ve Türkiye-AB İlişkileri (Nationalism and Turkey-EU Relations). İstanbul: TESEV.

Sarıbay, A.Y. (2002). "Kültürel Bir Olgu Olarak Globalleşme (Globalization as a Cultural Phenomenon)," in A.Y. Sarıbay et al. (eds.), Siyasi Ekonomik ve Kültürel Boyutlartyla Küreselleşme (Globalization with its Political, Economic and Cultural Dimensions): 45-54. İstanbul: Ufuk.

Smith, A.D. (2002). Nation and Nationalism in a Global Era (Küreselleşme Çağında Milliyetçilik). (Trans. Derya Kömürcü), İstanbul: Everest.

Türkeş, A. (1979). Konuşmalar (Conversations), Ankara: Hasret.

Uzun, T. (2005). Türk Milliyetçiliği ve MHP (Turkish Nationalism and the MHP). Ankara: Ebabil.

Yanardağ, M. (2002). “MHP'nin Geleceği: Sonuçlar ve Olasılıklar (The Future of the MHP: Results and Probabilities)," in S. Öngider (ed.), Milliyetçilik, Faşizm ve MHP (Nationalism, Fascism and the MHP): 15-38. İstanbul: Aykırı Güncel. 


\section{MHP Head Office's Documents and Devlet Bahçeli's Speeches}

Bahçeli, D. (1999a). "Sürmeli Oteli MKK, MYK ve Milletvekilleri Toplantısı Basın Açıklaması (The Press Release following the Meetings of The Central Decision Committee, The Central Executive Committee and Deputies in Sürmeli Hotel)," 1 May 1999. Available [on line] at:

http://www.mhp.org.tr/gbk.php?content=2911\&cat=20

------, (1999b). 3 May 1999 - “Milliyetçiler Günü Konuşması (Nationalists Day Speech),” Available [on line] at: http://www.mhp.org.tr/gbk.php?content=2914\&cat=20

------, (1999c). 2 November 1999. “Basın Toplantısı Konuşması.” (Press Conference Speech) Available [on line] at: http://www.mhp.org.tr/gbk.php?content=2913\&cat=20

------, (1999d). 14 December 1999 - “TBMM Grup Toplantısı Konuşması (Parliamentary Group Meeting Speech)," Available [on line] at: http://www.mhp.org.tr/gbk.php?content=2923\&cat=20

-----, (2000a). 24 February 2000 - “TBMM Grup Toplantısı Konuşması (Parliamentary Group Meeting Speech)," Available [on line] at: http://www.mhp.org.tr/gbk.php?content=352\&cat=19

------, (2000b). 19 May 2000 - “Ülkü Ocakları 19 Mayıs Şöleni Konuşması (Ülkü Ocakları-19 May Feast Speech," Available [on line] at: http://www.mhp.org.tr/gbk.php?content=339\&cat=19

-----, (2000c). 5 November 2000 - "MHP 6. Büyük Kurultay Konuşmas1 (6 $6^{\text {th }}$ Great Assembly of the MHP Speech)," Available [on line] at: http://www.mhp.org.tr/gbk.php?content=324\&cat=19

------, (2000d), 18 November 2000 - "MYK Toplantısı Konuşması (The Central Executive Committee Meeting Speech)," Available [on line] at: http://www.mhp.org.tr/gbk.php?content=321\&cat=19

------, (2000e). 21 November 2000 - "Basin Toplantıs1 (Press Conference)," Available [on line] at: http://www.mhp.org.tr/gbk.php?content=319\&cat=19

-----, (2000f). 28 November 2000 - "TBMM Grup Toplantısı Konuşması (Parliamentary Group Meeting Speech)," in Siyasette Ilke Ekonomide Kararlllık (Norm in Politics, Determination in Economics). Ankara: MHP Genel Merkezi.

------, (2000g). “TBMM'de 2000 Yılı Bütçe Görüşmelerinde Yapılan Konuşma (Speech Given at the Parliament during the Budget Discussions for the Year 2000), " in Yeniçă̆ın Eşiğinde Türkiye ve Dünya (Turkey and the World on the Verge of a New Age). Ankara: MHP Genel Merkezi.

------, (2000h).“Yeni Yıl Mesajı (New Year Message)," in Yeniçă̆ın Eşiğinde Türkiye ve Dünya (Turkey and the World on the Verge of the New Age). Ankara: MHP Genel Merkezi.

-----, (2002a). 31 January 2002 - “TBMM Grup Konuşması (Parliamentary Group Meeting Speech).” Available [on line] at: http://www.mhp.org.tr/gbk.php?content=221\&cat=17 
------, (2002b). Son Gelişmeler Işı̆̆ında Türkiye’nin AB Üyeliği ve Milliyetçi Hareket Partisi Temel Yaklaşım Biçimimiz ve Görüşlerimiz (EU Membership of Turkey in the Light of the Recent Developments and the MHP - Our Main Approach and Opinions). Ankara: MHP Genel Merkezi.

-----, (2003a). 1 June 2003 -“Basin Toplantıs1 (Press Conference).” Available [on line] at: http:// www.mhp.org.tr/gbk.php?content $=200 \&$ cat $=16$

------, (2003b). "7 Aralık 2003 İl-İlçe Başkanları Toplantısının Açılış Konuşması (Opening Speech of the Provincial and District Presidents' Meeting on 7 December 2003)," in AKP Iktidarının Bir Yıllık İcraatı (One-Year Performance of AKP Government) Ankara: MHP Genel Merkezi.

------, (2003c). AKP İktidarının 90 Günü ve Son Gelişmeler (90 Days of the AKP Government and the Recent Developments). Ankara: MHP Genel Merkezi.

-----, (2003d). 6. Ayında AKP İktidart-Gelişmeler, Gerçekler, Uyarılar (The AKP Government at its $6^{\text {th }}$ Month - Developments, Facts and Warnings). Ankara: MHP Genel Merkezi.

------, (2003e). AKP İktidarının Bir Yıllık İcraatı (One-Year Performance of the AKP Government). Ankara: MHP Genel Merkez Yayınları.

------, (2005). 11 November 2005 - “Basin Toplantıs1 (Press Conference)." Available [online] at: http://www.mhp.org.tr/gbk.php?content=114\&cat=14

------, (2006a). 8 December 2006 - “Avrupa Birliği ile Kıbrıs Pazarlı̆̆ı Hakkındaki Yazılı Basın Açıklaması (Written Press Release on the EU and Cyprus Bargain)." Available [on line] at: http://www.mhp.org.tr/gbk.php?content=61\&cat=13

------, (2006b). 15 December 2006 - “AB Zirve Kararları Sonrası Türkiye-AB İlişkilerinde Gelinen Nokta Hakkındaki Yazılı Basın Açıklaması (Written Press Release on the Recent Situation of Turkey-EU Relations after the Decisions of the Summit)." Available [on line] at: http://www.mhp.org.tr/gbk.php?content=60\&cat=13

------, (2007a). 15 February 2007 - "MKY Toplantısı Öncesi Basın Toplantısı Konuşması (Press Confrence Speech before the Central Executive Committee Meeting)." Available [on line] at: http://www.mhp.org.tr/gbk.php?content=49\&cat=12

-----, (2007b). 25 February 2007 - “1. Bölge İstişare Toplantısı ( $1^{\text {st }}$ Region Consultation Meeting).” Available [on line] at: http://www.mhp.org.tr/gbk.php?content $=47 \&$ cat $=12$

------, (2007c). 31 March 2007-“5. İstişare Toplantısı Konuşması-Adana (5 ${ }^{\text {th }}$ Consultation Meeting Speech-Adana).” Available [on line] at: http://www.mhp.org.tr/gbk.php?content=36\&cat=12

------, (2007d). 21 April 2007-“7. Bölge İstişare Toplantıs1-Konya (7 $7^{\text {th }}$ Region Consultation MeetingKonya).” Available [on line] at: http://www.mhp.org.tr/gbk.php?content=32\&cat=12

MHP (1973; 1977). Milliyetçi Hareketin El Kitabı (Manual of Nationalist Movement). Ankara: Emel Matbaacılık. 
(2004a). “2004 Avrupa Komisyonu'nun Türkiye İlerleme Raporu, Etki Raporu ve TavsiyeleriGenel Değerlendirme Raporu (European Commission's Progress Report Impact Report and Recommendations on Turkey in 2004, -General Evaluation Report).” Ankara: MHP Genel Merkezi.

-----, (2004b). “AKP’nin Teslimiyet Belgeleri - AB Türkiye İlerleme Raporu-Tavsiyeler (The AKP's Surrender Documents - The EU's Progress Report on Turkey-Recommendations).” Ankara: MHP Genel Merkezi.

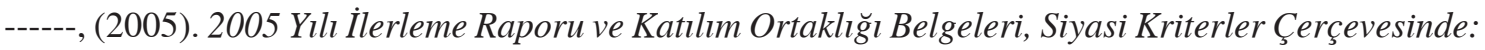
Talep ve Dayatmalar-AB'nin Türkiye Hakkında Dikkat Çeken Tespitleri. (2005 Progress Report and EU Accession Partnership Documents, the Demands and Impositions within the Framework of the Political Criteria-EU's Striking Findings about Turkey). Ankara: MHP Genel Merkezi AR-GE.

------, (2006a). 2006 Yılı İlerleme Raporu ve Strateji Belgesi Siyasi Kriterler Çerçevesinde: Talep ve Dayatmalar-AB'nin Türkiye Hakkında Olumsuz Tespitleri ve Beklentileri. (2006 Progress Report and Strategy Document, Demands and Impositions within the Framework of the Political Criteria-EU's Negative Findings and Expectations from Turkey). Ankara: MHP AR-GE.

-----, (2006b). İste AKP'nin Avrupa Birliği Yol Haritası - Çıkmaz Sokak. (The AKP's EU Map Dead-end Street). Ankara: MHP Genel Merkezi-AR-GE. 